\title{
THE RURAL SECTOR SENSITIVITY ON CYCLICAL FLUCTUATION: EVIDENCE FROM OECD MEMBERS AND POST-SOCIALIST COUNTRIES
}

\author{
Olena Tkachenko ${ }^{1},{ }^{*}$ Yuriy Bilan$^{2}$, Maryia Drobyazko ${ }^{3}$ \\ 1.PhD, Assoc. prof. Kyiv National Economic University named after Vadym Hetman. Peremogy \\ avn. 54/1.03680, Kyiv, Ukraine.Tel.+380679372199. E-mail. olena.vadumivna@ukr.net \\ 2.Dr hab. prof. Alexander Dubcek University Trenčín, Slovakia. E-mail. \\ yuriy_bilan@yahoo.co.uk \\ 3.PhD, Kyiv National Economic University named after Vadym Hetman. Peremogy avn. 54/1. \\ 03680, Kyiv, Ukraine.Tel.+380936364555.E-mail.mariadrobyazko@gmail.com
}

Received 0502 2019; accepted 14032019

The stabilization policy of the state should consider the sensitivity of various sectors of the economy to cyclical fluctuations. This actualizes the problem of assessing the sensitivity of the agricultural sector of post-socialist countries to cyclical fluctuations of the economy. The purpose of the article is to provide a comparative assessment of the sensitivity of share agricultural sector to cyclical fluctuations in developed (post-industrial) and post-socialist countries. The generalizing intensity index of cyclic fluctuations was used as an explanatory variable, and the characteristics of the variability of the agricultural sector share in GDP (based on a modified mean square deviation) was used as a dependent variable. The obtained estimates of the model parameters shows that the long-term trend of reducing the share of the agrarian sector is decaying. However, with the attenuation of the trend component of the series, the cyclic component remains very noticeable and the relative fluctuations of the share of the agricultural sector (around a very small absolute value) remain significant.

Keywords: economic cycle, agriculture, economic sector structure, intensity of cyclicity, structural changes.

JEL codes: E32, L16, O18.

\section{Introduction}

History of industrial civilization proves that cyclicity is the single option form of development. Downturns and crises prove the intensification of the adaptation of economic entities to new resource, institutional and structural conditions, and growth proves the rapid spread of the most effective ways of adaptation. Despite significant advances of economics in building universal cyclical models, explaining the dynamics of any particular economic system requires specifying its specific mechanisms for transmitting "economic impulses", institutional constraints,

Copyright (C) 2019 The Authors. Published by Vytautas Magnus University, Lithuanian Institute of Agrarian Economics. This is an open access article distributed under the terms of the Creative Commons Attribution NonCommercial 4.0 (CC BY-NC 4.0) license, which permits unrestricted use, distribution, and reproduction in any medium, provided the original author and source are credited. The material cannot be used for commercial purposes. 
structural prerequisites of higher or lower sensitivity to "shocks" of various nature. One of the directions of such a "concrete definition" of universal models of cyclicity is the elaboration of the specificity of certain economic sectors sensitivity to cyclical fluctuations, based on the assumption that such sensitivity varies at different stages of development.

In the framework of this study, the specific features of the reaction of the agrarian sector to cyclical fluctuations in post-industrial economic systems and postsocialist countries (where the share of the agrarian sector is relatively large) are determined.

This work is based on the hypothesis that in a sufficiently long period, it is possible to determine the connection between the intensity of cyclical fluctuations and the dynamism of changes in the sectoral structure of the economy.

Therefore, the first aim of this article is to test the hypothesis that a more intense cyclical nature of economic dynamics is associated with a greater variability of the sectoral structure of the national economy. Empirical confirmation of this hypothesis will be in the presence of a functional relationship between the intensity of cyclical fluctuations in the economy (further, we will explain what we mean by "intensity of cyclical fluctuations" and how we suggest evaluating it) and structural changes.

The second aim is to confirm the thesis about the attenuation of structural fluctuations to the extent of the transition to the post-industrial structure of the national economy on the example of the agrarian sector (namely, reducing its share together with the growth of the service sector are the most clearly expressed tendency of forming of post-industrial structure of the national economy).

The third aim is to clarify the differences between developed (post-industrial) countries from post-socialist (which are characterized by a relatively high share of the agricultural sector) based on such a criterion as the sensitivity of the share of the agricultural sector to cyclical fluctuations.

The database contains indicators of the dynamics of real GDP and the share of the agrarian sector in GDP for the two groups of countries. The first group includes countries of the Organization for Economic Cooperation and Development ("OECD"). The second group includes post-socialist countries comparable by their sizes of economy and its resource potential with the economy of Ukraine, since it will be the modernization of its economic policy that will be the topic our further work, continuing the research topics.

Comparison of the groups of "OECD countries" and "post-socialist countries" is relevant for two reasons. First, there is a significant differentiation of the sectoral structure in groups: while in the economies of almost all OECD countries, the agrarian sector occupies no more than $3 \%$, in the post-socialist countries, it ranges from $9 \%$ to $26 \%$. Thus, considering the group of "OECD countries" as a group in which the sectoral structure of the economy is close to post-industrial, yet not fully correct, still does not lead to significant distortions at this stage. 
Second, the countercyclical and structural policies of the post-socialist countries are formed under influence of more developed countries and the adaptation of this policy to national specificity requires at least an understanding of the differences in the response of the economy as a whole and its individual sectors to cyclical fluctuations in the economic situation.

\section{Literature analysis}

In the majority of literature suggesting a quantitative assessment of cyclicity, there are three main directions. The first group of works is devoted to identifying the phases of cycles (first of all - turning points), identify the factors determining the amplitude of oscillations and the possibilities of compensating for their action, in accordance with the goals of the anticyclic policy.

At the same time, cyclical indicators are dependent variables, and the financial, institutional and structural parameters of the economy (including the sectoral structure), as well as the scope and direction of state regulatory policy, are factors explaining the amplitude and duration of oscillations Hall et al. (2003), Stock and Watson (1999), Zarnowitz and Ozyildirim (2002), Schmukler et al. (2006), Shvedovsky et al. (2016).

In such works, the task of assessing cyclicity is solved in the context of the integration of various indicators as part of a single (applicable for a comprehensive assessment of the cycle phase) index of macroeconomic conditions. In fact, most of the works are devoted to the "horizontal", i.e. based on several indicators, integration, but not vertical one (for a certain period of time).

The second direction combines works devoted to assessing the impact of cyclical impulses on the parameters of the functioning of the economy, including the conditions for expanding the scale of activity in various sectors and types of economic activity, the nature of income distribution, the prevalence of various models of economic behavior, such as Blanchard and Simon (2001), Cecchetti et al. (2006), Clarida et al. (2000), Elsb et al. (2013) Tvaronavičienè and Gatauti (2017), Kumar at al. (2018), Kharlamova et al. (2018).

The interaction of the dynamics of aggregated and sectoral indicators in the context of bilateral relations and mutual influence is considered in the framework of the third direction. In fact, while in the two previous directions, such mutual interaction is taken into account implicitly (due to the use of the principles of multiplication and acceleration of the "initial" cyclic impulses), in the third direction, the interaction of "industry shocks" and the macroeconomic environment falls into the focus of Foerster et al. (2011), Abraham and Katz (1986), Long and Plosser (1987), Rose and Spiegel (2009).

The statement of the problem of our research makes it the most related with the third direction. At the same time, the basic position common in literature on 
cyclicity is the dominance of the oscillation amplitude as a basis for assessing its "intensity" (the terms "depth" and "scope" of oscillations are more common) (The Conference Board, 2002), namely real GDP are defined as the "core of cyclicality" (Stock, \& Watson, 1999). This indicator is traditionally considered as an indicator of the "coincident" group, i.e. without lagging or leading compared to the dynamics of the cycle (The Conference Board, 2002).

As an indicator of the structure in modern literature, the shares of the employees and the value added of the industry are used in general indicators of the national economy (Tase, 2016). We used the second one, both because of its more direct connection with the selected cyclicity index, and because of the similar relation to the phases of the cycle. So, in particular, the dynamics of employment may lag behind the dynamics of the cycle, both due to institutional constraints (adaptation of the real volume to the actual needs of producers in the labor force may require considerable time), and due to the fact that possible fluctuations in labor productivity can act as a "compensator" and significantly "blur" the impact of the cycle on the structure of employment.

Since the structure indicator depends both on the response to cyclical fluctuations of the agriculture itself and other sectors, it is possible to interpret the results obtained only in the context of the comparative characteristics of the sensitivity of the agricultural, industrial and service sectors of the economy to the influence of the business cycle.

As a tool for assessing the sensitivity of industries and sectors of the economy to cyclic impulses, elasticity coefficients are mainly used, and they reflect the percentage change in the dependent indicator when the factor indicator changes by one percent. The algorithm for calculating such indicators depends on the form of the function chosen for modeling the dependency (The Conference Board, 2002).

The important difference between our study and the widespread literature is that it implies an assessment of the intensity of fluctuations not for a single phase of the cycle, but for several complete business cycles (3-7 years long). This difference is connected with the need to take into account not only the amplitudes of oscillations, but also their frequencies, i.e. the number of "break points" for a period of time. In fact, it is an indicator that can be considered reverse to a more common indicator of the duration of the cycle phase.

Thus, the proposed generalizing indicator of the intensity of cyclical fluctuations in GDP will reflect the contribution of two components. The first component is the dispersion of the values of the time series around the trend. The second is the frequency of changing the direction of dynamics (growth / decline for indicators of cyclicity, expansion / contraction - for indicators of structure). 


\section{Methodology}

The estimation of the cyclical phase was carried out on the basis of real GDP dynamics. In the literature, it is interpreted as a procyclical, coincident indicator. This means that its dynamics coincides with the general directionality of the phases of the cycle and does not have a time lag, i.e. is neither advancing nor lagging behind the dynamics of the cycle.

This choice was made due to the fact that the focus of our study is the most general connection between the intensity of cyclical fluctuations and the variability of the sectoral structure of the economy (namely, with the dynamics of the share of its agrarian sector). Further, we will include in the model indicators of the dynamics of the general price level and fluctuations in relative prices (for example, changes in the correlation of prices of producers of agricultural products and industrial production).

To smooth the series and eliminate its seasonal component, we applied the Hodrick-Prescot filter at the first stage of data processing. At the second stage, based on the traditional indicator of the variability of the series (variance), an indicator was calculated and it reflects only the cyclical component of variability. The dispersion index does not meet our objectives, since it will estimate the variability of a dynamically growing series that is obviously higher than the series with similar fluctuations, with a less pronounced growth trend. Therefore, three changes have been made to the classical dispersion index.

First, the basis for determining the deviations of the actual values of the series was not the average value, but the value of the linear trend. This made it possible to eliminate differences in variability, given by the range of variation, and the cyclical nature of a dynamically growing series would not be assessed higher than the cyclicity of a similar variable, but with a smaller variation scale.

Second, to ensure comparability of the indicator for countries with different GDP values, we calculate the relative size of the sum of the squares of deviations of the actual (smoothed) values from the trend. For this, instead of absolute deviation, its relation to the trend value is used. This makes the indicator independent of the absolute value of GDP. Thus, it is not the variance that is calculated, but the square root of the average relative deviation of the actual (smoothed) value from the trend value (ADT):

$$
A D T=\sqrt[2]{\sum_{t=1}^{n} \frac{\left(S_{t}-T_{t}\right)^{2}}{T_{t}} / n}
$$

where:

Tt are the series values for period t according to a linear trend;

St is the values of the smoothed series;

$n$ is the number of elements in the series 
Third, the average relative deviation of the actual values from the values of the linear trend is multiplied by the number of changes in the sign of the deviation, as an indicator of the frequency of cyclic oscillations (the reciprocal of the duration of the cycle phase). So, if half of the "n" actual values are greater than the trend value, and half less, then the number of "deviation sign changes" can vary from n-1 (for the case when a negative deviation is necessarily followed by a positive, and a positive deviation is followed by negative) to "1". The latter value occurs in the case when all positive deviations follow each other in a continuous series, and then all negative deviations are also a continuous series.

Thus, the formula of the coefficient we propose for estimating the intensity of cyclical fluctuations (KIC), which will reflect both the frequency of changing the directionality of the dynamics and the spread of values around the trend line, can be determined as follows:

$$
K I C=A D T \times F R,
$$

Where $F R$ is the frequency of change of the sign of deviation for the retrospective period;

To compare the indicator of intensity of cyclic fluctuations with the indicator of intensity of changes in the structure, the specific indicator of changes in the intensity of cyclic fluctuations of the structure $(\mathrm{KICu})$ was calculated. It assesses the dynamics of structural changes, based on the intensity of cyclical fluctuations in the national economy, and is calculated by the formula:

$$
K I C u=K I C s / K I C g d p
$$

Where KICgdpis the index of intensity of cyclical fluctuations in GDP; KICs is the index of intensity of cyclical fluctuations of the share of the agrarian sector in $G D P$;

The obtained calculations allow to estimate how the intensity of cyclical fluctuations in GDP correlates with the share of the agrarian sector according to two criteria: the dispersion of values around the trend and the frequency of changes in the direction of dynamics (how often expansion is replaced by contraction, and vice versa).

The proposed average does not take into account to what extent the dynamics of the factor (fluctuations in GDP) and dependent variable (fluctuations in the share of the agricultural sector) coincide in time. For the primary characteristic of the relation "intensity of cyclic fluctuations - intensity of structural changes," this is not necessary. However, in further work, in parallel with the expansion of the model and the introduction of additional factor indicators, which should increase its explanatory capacity, it is necessary to evaluate not only the generalized (for the entire period as a whole) similarity of the dispersion of indicators and the variability of their dynamics, but also the measure of their coincidence in time. Therefore, we have 
already supplemented the analysis on the basis of summarizing (for the entire period) coefficients with a rather simplified regression analysis.

The article contains only a preliminary assessment of the nature of relation. To do this, we used the simplest linear function of the form:

$$
G D P_{\text {agro }}=b_{0}+b_{1} \times G D P
$$

Where GDP agrois a the share of the agricultural sector in GDP; GDP - real GDP.

The logarithmic form of representation of the factor and dependent indicator is not used in this case, since the contribution of the growth rate of the value added of the agricultural sector to the overall GDP growth rate can be expressed by a simple linear formula:

$$
G R_{k} \times S H_{k}=G R_{t}
$$

Where GRk is the growth rate of real GDP in the agrarian sector; SHk is the share of the agrarian sector in the national economy's GDP in the reporting period (period t); GRt - GDP growth rate of the national economy.

\section{Results and discussion}

Calculated for the period 1991 - 2016 coefficients of intensity of cyclical fluctuations in GDP and the share of the agrarian sector in the economy for 35 OECD countries and 10 post-Soviet countries are provided in Table 1.

Both the general indicator of the intensity of cyclical fluctuations and its first component (the average for the period relative deviation from the trend - the indicator of the dispersion of values around the trend) of the share of the agricultural sector in GDP is much higher than the indicator of the intensity of fluctuations in GDP. For the vast majority of OECD member countries (24 out of 35 ), this excess is more than 4 times.

The highest excess of the dispersion of the structure indicators in comparison with the GDP indicators (more than ten times) is typical for ten OECD member countries. For none of the OECD member countries, the dispersion of the structure indicators was for the period of 1990-2016 lower than dispersion of GDP figures.

For post-socialist countries, the excess of the dispersion of the share of the agrarian sector in GDP compared to the dispersion of GDP is much less - the predominant range is from 1.1 to 2 (data from seven countries out of ten fall into it). For Azerbaijan, the dispersion around the trend of GDP values is higher than the share of the agrarian sector in GDP. Two more post-socialist countries have an indicator of dispersion of the share of the agrarian sector in GDP that exceeds more than twice the dispersion of GDP values. 
Table 1. The coefficients of intensity of cyclical fluctuations in GDP and the share of the agricultural sector in GDP, as well as their components for 1990 - 2016 *

\begin{tabular}{|c|c|c|c|c|c|c|}
\hline & \multicolumn{3}{|c|}{ Indicators for GDP } & \multicolumn{3}{|c|}{$\begin{array}{c}\text { Indicators for share of agrarian } \\
\text { sector in GDP }\end{array}$} \\
\hline & $\begin{array}{l}\text { The average } \\
\text { relative } \\
\text { deviation of } \\
\text { the } \\
\text { smoothed } \\
\text { GDP values } \\
\text { from the } \\
\text { value along } \\
\text { a linear } \\
\text { trend }\end{array}$ & $\begin{array}{l}\text { The number } \\
\text { of times the } \\
\text { deviation } \\
\text { sign } \\
\text { changes } \\
\text { (more / less } \\
\text { than the } \\
\text { value } \\
\text { according to } \\
\text { the trend) }\end{array}$ & $\begin{array}{l}\text { Coefficien } \\
t \text { of } \\
\text { intensity } \\
\text { of cyclical } \\
\text { of } \\
\text { luctuations }\end{array}$ & $\begin{array}{l}\text { The average } \\
\text { relative } \\
\text { deviation of } \\
\text { the } \\
\text { smoothed } \\
\text { GDP values } \\
\text { from the } \\
\text { value along } \\
\text { a linear } \\
\text { trend }\end{array}$ & $\begin{array}{l}\text { The number } \\
\text { of times the } \\
\text { deviation } \\
\text { sign } \\
\text { changes } \\
\text { (more / less } \\
\text { than the } \\
\text { value } \\
\text { according to } \\
\text { the trend) }\end{array}$ & $\begin{array}{l}\text { Coefficie } \\
\text { nt of } \\
\text { intensity } \\
\text { of } \\
\text { cyclical } \\
\text { fluctuati } \\
\text { ons }\end{array}$ \\
\hline Australia & 1.1 & 4.0 & 4.4 & 8.3 & 5.0 & 41.6 \\
\hline Austria & 2.1 & 2.0 & 4.1 & 10.0 & 2.0 & 20.0 \\
\hline Belgium & 1.8 & 3.0 & 5.4 & 26.6 & 2.0 & 53.2 \\
\hline Canada & 2.0 & 3.0 & 6.0 & 30.3 & 3.0 & 91.0 \\
\hline Switzerland & 1.9 & 2.0 & 3.7 & 12.8 & 2.0 & 25.6 \\
\hline Chile & 2.7 & 4.0 & 10.8 & 12.3 & 2.0 & 24.7 \\
\hline $\begin{array}{l}\text { Czech } \\
\text { Republic }\end{array}$ & 4.0 & 6.0 & 23.8 & 17.6 & 3.0 & 52.8 \\
\hline Germany & 1.0 & 7.0 & 6.8 & 5.7 & 4.0 & 22.8 \\
\hline Denmark & 3.3 & 2.0 & 6.7 & 14.4 & 6.0 & 86.2 \\
\hline Spain & 6.1 & 2.0 & 12.2 & 31.6 & 2.0 & 63.2 \\
\hline Estonia & 16.1 & 2.0 & 32.2 & 30.4 & 2.0 & 60.9 \\
\hline Finland & 6.0 & 3.0 & 17.9 & 13.6 & 2.0 & 27.2 \\
\hline France & 2.4 & 2.0 & 4.8 & 6.7 & 4.0 & 26.7 \\
\hline Great Britain & 3.0 & 2.0 & 5.9 & 14.2 & 2.0 & 28.5 \\
\hline Greece & 12.8 & 2.0 & 25.6 & 30.9 & 2.0 & 61.8 \\
\hline Hungary & 6.2 & 4.0 & 24.9 & 29.9 & 2.0 & 59.9 \\
\hline Ireland & 8.5 & 4.0 & 33.9 & 55.4 & 3.0 & 166.1 \\
\hline Iceland & 17.7 & 2.0 & 35.3 & 33.4 & 4.0 & 133.6 \\
\hline Israel & 2.7 & 2.0 & 5.4 & 21.5 & 2.0 & 43.0 \\
\hline Italy & 4.3 & 2.0 & 8.5 & 6.8 & 2.0 & 13.6 \\
\hline Japan & 1.4 & 5.0 & 7.0 & 19.3 & 2.0 & 38.6 \\
\hline Korea & 1.2 & 8.0 & 9.3 & 12.4 & 2.0 & 24.7 \\
\hline Luxemburg & 2.8 & 4.0 & 11.2 & 34.8 & 2.0 & 69.6 \\
\hline Latvia & 16.5 & 2.0 & 33.1 & 31.5 & 2.0 & 63.1 \\
\hline Mexico & 1.9 & 7.0 & 13.3 & 14.6 & 2.0 & 29.2 \\
\hline $\begin{array}{l}\text { The } \\
\text { Netherlands }\end{array}$ & 3.7 & 2.0 & 7.5 & 12.0 & 2.0 & 24.0 \\
\hline Norway & 2.9 & 2.0 & 5.8 & 17.0 & 2.0 & 34.1 \\
\hline $\begin{array}{l}\text { New } \\
\text { Zealand }\end{array}$ & 1.8 & 6.0 & 10.6 & 9.6 & 6.0 & 57.8 \\
\hline Poland & 2.7 & 2.0 & 5.4 & 30.4 & 4.0 & 121.7 \\
\hline
\end{tabular}




\begin{tabular}{|l|c|c|c|c|c|c|} 
Portugal & 5.7 & 2.0 & 11.5 & 31.6 & 2.0 & 63.2 \\
\hline Slovakia & 6.8 & 4.0 & 27.2 & 24.0 & 2.0 & 48.0 \\
\hline Slovenia & 19.3 & 2.0 & 38.7 & 28.6 & 2.0 & 57.2 \\
\hline Sweden & 2.3 & 4.0 & 9.2 & 10.1 & 2.0 & 20.3 \\
\hline Turkey & 8.9 & 2.0 & 17.9 & 10.9 & 4.0 & 43.4 \\
\hline USA & 2.8 & 2.0 & 5.5 & 25.9 & 4.0 & 103.4 \\
\hline Albania & 4.1 & 5.0 & 20.5 & 26.2 & 3.0 & 78.6 \\
\hline Armenia & 13.4 & 4.0 & 53.5 & 18.6 & 3.0 & 55.9 \\
\hline Azerbaijan & 26.0 & 3.0 & 77.9 & 18.9 & 2.0 & 37.9 \\
\hline Bulgaria & 6.9 & 4.0 & 27.5 & 19.2 & 4.0 & 76.7 \\
\hline Belarus & 13.0 & 3.0 & 38.9 & 16.0 & 2.0 & 32.0 \\
\hline Georgia & 21.0 & 4.0 & 84.0 & 33.8 & 3.0 & 101.3 \\
\hline Kazakhstan & 15.5 & 4.0 & 61.9 & 22.6 & 3.0 & 67.9 \\
\hline Romania & 6.5 & 4.0 & 25.9 & 10.9 & 5.0 & 54.7 \\
\hline Russia & 12.9 & 3.0 & 38.7 & 19.9 & 2.0 & 39.9 \\
\hline Ukraine & 20.5 & 3.0 & 61.6 & 22.7 & 4.0 & 91.0 \\
\hline
\end{tabular}

* - calculated by authors according to https://data.worldbank.org/

The variability of the nature of deviations (the number of changes of the positive and negative deviation and vice versa) is slightly higher for the GDP indicators than for the structure indicators (share of the agricultural sector), but not significantly. The same number of changes in the sign of deviations for both GDP and structure indicators prevail (this situation is observed in 15 OECD countries and one post-socialist country).

Thus, the generalized indicator of the intensity of cyclic fluctuations for the period of $1990-2016$, for indicators of structure, is predominantly higher than for indicators of GDP. The indicator we propose (the product of the average relative deviation from the trend by the number of changes in the sign of deviation) is higher for the structure indicator than for the GDP indicator for all OECD countries and for all post-socialist countries.

Such empirical results make it possible to clarify the widespread (for example, Adelman (2001), Dimitri et al. (2005) theoretical premise, according to which, the formation of a prominent post-industrial economic structure (with evident predominance of the service sector) leads to a stabilization of the agricultural sector. Indeed, the long-term trend of decline in the share of the agricultural sector is fading away. And our calculations showed that the relative fluctuations of the share of the agricultural sector in GDP are somewhat lower for OECD countries (for which the post-industrial structure of economics is typical) than the post-socialist countries. On average (unweighted average value), the cyclical fluctuation intensity factor for structure indicators was 54.3 for a group of 35 OECD member countries and 63.6 for a group of post-socialist countries. 
However, at the same time, with the attenuation of the trend component of the series, the cyclical one remains very noticeable and the relative fluctuations in the share of the agrarian sector (around a very small absolute value) remain significant.

The obtained results are confirmed by the results of the modeling of the "GDP - the share of the agrarian sector in GDP" relation using a linear function (the simulation results are shown in Table 2).

For a linear function, the elasticity coefficient was calculated by the formula:

$$
E=b_{1} \times \frac{\bar{x}}{\bar{Y}}
$$

where $b_{1}$ isfunction parameter estimate with variable; $\bar{x}$ isaverage value of the factor variable; $\bar{Y}$ isaverage value of the calculated (by function) values of the dependent variable;

Table 2. Estimations of parameters and explaining power of functions for the dependence "GDP - the share of the agrarian sector in GDP"*

\begin{tabular}{|l|c|c|c|c|c|}
\hline & $\begin{array}{l}\text { Correlation } \\
\text { coefficient of } \\
\text { dependent and } \\
\text { explanatory } \\
\text { variables }\end{array}$ & $\begin{array}{l}\text { Determine- } \\
\text { ation } \\
\text { coefficients }\end{array}$ & $\begin{array}{l}\text { Estimation of } \\
\text { the parameter } \\
\text { with the factor } \\
\text { variable }\end{array}$ & $\begin{array}{l}\text { Standard } \\
\text { error of } \\
\text { assessment }\end{array}$ & $\begin{array}{l}\text { Coefficient of } \\
\text { elasticity of } \\
\text { the dependent } \\
\text { variable from } \\
\text { the factor }\end{array}$ \\
\hline Australia & -0.8607 & 0.7407 & -0.0022 & 0.0003 & -0.5788 \\
\hline Austria & -0.9542 & 0.9106 & -0.0094 & 0.0006 & -1.8648 \\
\hline Belgium & -0.9897 & 0.9794 & -0.0050 & 0.0002 & -2.0885 \\
\hline Canada & 0.4509 & 0.2033 & 0.0005 & 0.0004 & 0.4242 \\
\hline Switzerland & -0.2558 & 0.0654 & -0.0046 & 0.0036 & -0.1710 \\
\hline Chile & -0.8794 & 0.7733 & -0.0147 & 0.0016 & -0.7961 \\
\hline Czech & -0.8838 & 0.7812 & -0.0144 & 0.0016 & -1.3160 \\
\hline Republic & -0.9145 & 0.8363 & -0.0004 & 0.0000 & -1.4156 \\
\hline Germany & -0.9641 & 0.9295 & -0.0256 & 0.0014 & -3.2251 \\
\hline Denmark & -0.5083 & 0.2584 & -0.0020 & 0.0007 & -0.8918 \\
\hline Spain & -0.3624 & 0.1314 & -0.0355 & 0.0199 & -0.2889 \\
\hline Estonia & -0.9478 & 0.8983 & -0.0230 & 0.0016 & -1.4820 \\
\hline Finland & -0.9743 & 0.9493 & -0.0015 & 0.0001 & -1.6687 \\
\hline France & -0.9519 & 0.9062 & -0.0008 & 0.0001 & -2.0045 \\
\hline Great Britain & -0.7212 & 0.5202 & -0.0264 & 0.0055 & -1.6292 \\
\hline Greece & -0.9348 & 0.8738 & -0.0388 & 0.0032 & -1.7175 \\
\hline Hungary & -0.8600 & 0.7395 & -0.0242 & 0.0031 & -1.9828 \\
\hline Ireland & -0.8281 & 0.6858 & -0.4095 & 0.0636 & -0.7178 \\
\hline Iceland & -0.7631 & 0.5823 & -0.0026 & 0.0005 & -0.3322 \\
\hline Israel & -0.8997 & 0.8095 & -0.0031 & 0.0003 & -2.6651 \\
\hline Italy & -0.9422 & 0.8878 & -0.0010 & 0.0001 & -3.3317 \\
\hline Japan & -0.9502 & 0.9028 & -0.0037 & 0.0002 & -1.1986 \\
\hline Korea & -0.9717 & 0.9442 & -0.0251 & 0.0013 & -1.9599 \\
\hline Luxemburg & & & & & \\
\hline
\end{tabular}


Management Theory and Studies for Rural Business and Infrastructure Development

ISSN 2345-0355. 2019. Vol. 41. No. 1: 93-106

Article DOI:_https://doi.org/10.15544/mts.2019.09

\begin{tabular}{|l|c|c|c|c|c|}
\hline Latvia & -0.9164 & 0.8397 & -0.1072 & 0.0102 & -0.8567 \\
\hline Mexico & -0.8199 & 0.6722 & -0.0027 & 0.0004 & -1.1670 \\
\hline The & & & & & \\
Netherlands & -0.9768 & 0.9541 & -0.0066 & 0.0003 & -1.9947 \\
\hline Norway & -0.8780 & 0.7709 & -0.0103 & 0.0011 & -1.5674 \\
\hline New Zealand & -0.5449 & 0.2969 & -0.0171 & 0.0054 & -0.2784 \\
\hline Poland & -0.8120 & 0.6594 & -0.0043 & 0.0007 & -0.8767 \\
\hline Portugal & -0.9540 & 0.9101 & -0.0404 & 0.0028 & -3.8338 \\
\hline Slovakia & -0.8553 & 0.7315 & -0.0186 & 0.0025 & -0.4975 \\
\hline Slovenia & -0.9230 & 0.8519 & -0.0505 & 0.0046 & -1.0353 \\
\hline Sweden & -0.9481 & 0.8990 & -0.0072 & 0.0005 & -1.4950 \\
\hline Turkey & -0.8516 & 0.7252 & -0.0075 & 0.0009 & -0.7842 \\
\hline USA & -0.3412 & 0.1164 & 0.0000 & 0.0000 & -0.1924 \\
\hline Albania & -0.8120 & 0.6594 & -1.3615 & 0.1998 & -1.0904 \\
\hline Armenia & -0.8571 & 0.7347 & -1.1090 & 0.1360 & -0.6592 \\
\hline Azerbaijan & -0.8252 & 0.6810 & -0.1380 & 0.0193 & -0.8149 \\
\hline Bulgaria & -0.9357 & 0.8755 & -0.1817 & 0.0140 & -1.9017 \\
\hline Belarus & -0.7291 & 0.5315 & -0.0768 & 0.0147 & -0.7466 \\
\hline Georgia & -0.7077 & 0.5008 & -1.5013 & 0.3059 & -1.4672 \\
\hline Kazakhstan & -0.7862 & 0.6182 & -0.0286 & 0.0046 & -0.8681 \\
\hline Romania & -0.9310 & 0.8668 & -0.0745 & 0.0060 & -2.0326 \\
\hline Russia & -0.5444 & 0.2964 & -0.0017 & 0.0005 & -0.8481 \\
\hline Ukraine & 0.1416 & 0.0200 & 0.0089 & 0.0127 & 0.2455 \\
\hline
\end{tabular}

* - calculated by authors according to https://data.worldbank.org/

The share of the agricultural sector in GDP is clearly a counter-cyclical indicator: negative and close to one signs in absolute value indicate the correlation coefficients between the vectors of data on GDP and the share of the agricultural sector in GDP for the vast majority of countries included in the sample. In addition, this is confirmed by a negative value of the coefficients at the factor variable (coefficients $b$ ) and indicate that during periods of growth (positive dynamics of GDP), the growth rates of the value added of the agricultural sector lag behind the growth rates of the value added of the industrial and services sectors. As a result, against the background of the growth of national production, a decrease in the share of the agrarian sector in GDP is fixed.

At the same time, during periods of negative growth rates (in the database, the bulk of the observed negative growth rates of GDP falls on post-socialist countries), it can be expected that the reduction rates of the added value of the agricultural sector will be lower than in the industrial and services sectors, which will cause an increase in the weight of the agricultural sector in the national GDP.

These results are consistent with the statement that the reduction in the share of the agrarian sector in the process of the formation of the post-industrial economy is a natural form of growth in the efficiency of national production. 
In addition, the coefficient of elasticity calculated by the formula (6) is higher than one for most of the countries included in the sample. This value of elasticity of the dependent variable (intensity of structure index fluctuations) from the factor

(intensity of GDP fluctuations) coincides with the results obtained by comparing generalized indicators for the entire retrospective period: the intensity of cyclical fluctuations of the agricultural sector share in GDP is higher than the intensity of such fluctuations in GDP.

\section{Conclusions}

1. The long-term trend of reducing the share of the agricultural sector is subsiding. At the same time, with the subsiding of the trend component of the series, the cyclical one remains very noticeable and the relative fluctuations in the share of the agrarian sector (around a very small absolute value) remain significant. Despite the fact that the relative fluctuations of the share of the agrarian sector in GDP are slightly lower for OECD countries (where the post-industrial structure of the economy is typical) than for post-socialist countries, in both groups, high values of the structure elasticity coefficients of GDP prevail. The latter indicates a rather high sensitivity of the share of agriculture to cyclical fluctuations in the economy, both in countries with a significant share of the agricultural sector and in countries with a pronounced post-industrial sectoral structure of the economy.

2. The share of the agricultural sector in GDP is clearly a counter-cyclical indicator. This indicates that, during periods of growth (positive dynamics of GDP), the growth rates of the value added of the agricultural sector lag behind the growth rates of the value added of the industrial and services sectors. As a result, together with growth in national production, the decline in the share of the agrarian sector in GDP is predominantly noticed, and in periods of negative growth rates, it can be expected that the rate of decline in the value added of the agrarian sector will be lower than in the industrial and services sectors.

3. OECD member countries are characterized by a significantly higher sensitivity of the share of the agrarian sector to GDP fluctuations, compared with post-socialist countries. Combined with the second conclusion (the counter-cyclical nature of the agrarian sector's share of GDP), this can be a prerequisite for a generalizing conclusion: cyclical crises do not play an important role in reducing the share of the agrarian component of GDP, but rather the opposite: positions of agricultural sector are somewhat strengthened during periods of negative macroeconomic dynamics. In developed countries (OECD member countries), this can be explained by a large-scale system of compensating state aid, and in postsocialist countries - by strengthening their export sector, which traditionally has a high proportion of agriculture, as well as a tendency to stabilize the unenviable role of an agricultural exporter due to crowding out high-tech industries, which are more vulnerable to crises, from the export during crisis periods. 


\section{Management Theory and Studies for Rural Business and Infrastructure Development \\ ISSN 2345-0355. 2019. Vol. 41. No. 1: 93-106}

Article DOI:_https://doi.org/10.15544/mts.2019.09

\section{References}

Abraham, K.G., Katz L. F. (1986). Cyclical Unemployment: Sectoral Shifts or Aggregate Disturbances? Journal of Political Economy, Vol 3. No 94: 507-522.

Adelman I. (2001). Fallacies in Development Theory and Their Implications for Policy. Frontiers of Development Economics, Oxford University Press, P. 103-134.

Blanchard, O., Simon J. (2001). The Long and Large Decline in U.S. Output Volatility. Brookings Papers on Economic Activity, No.1: 135-164.

Business Cycle Indicators Handbook (2002). The Conference Board. New-York. www.tcbindicators.org.

Cecchetti, S. G., Flores-Lagunes A., Krause S. (2006). Has Monetary Policy Become More Efficient? A Cross-Country analysis. The Economic Journal No. 116: 408- 433.

Clarida, R., GalJ., Getler M. (2000). Monetary Policy Rules and Macroeconomic Stability: Evidence and Some Theory. Quarterly Journal of Economics 115(1): 147-180.

Dimitri C., Effland A., and Conklin N. (2005). The 20th Century Transformation of U.S. Agriculture and Farm Policy / EIB-3 Economic Research Service/USDA.

Elsby, M. W., Hobijn B.SahinA.(2013) The Decline of the U.S. Labor Share. Brookings Papers on Economic Activity Fall: 1-52.

Foerster A. T., SarteP. G., WatsonM. W. (2011). Sectoral versus Aggregate Shocks: A Structural Factor Analysis of Industrial Production. Journal of Political Economy, 119(1): 1-38.

Hall R., Feldstein M., Frankel J., Gordon R., Romer C., Romer D., Zarnowitz V. (2003). The NBERR's Business-Cycle Dating Procedure // Business Cycle Dating Committee, National Bureau of Economic Research. July.

Kharlamova, G., Stavytskyy, A., \& Zarotiadis, G. (2018). The impact of technological changes on income inequality: the EU states case study. Journal of International Studies, 11(2): 76-94. doi:10.14254/2071-8330.2018/11-2/6 [03 12 2018]

Kumar, N., Al Mamun, A., Ibrahim, M. D. \& Yusoff, M. N. H. (2018). Entrepreneurial orientation and antecedents of low-income household heads in Kelantan, Malaysia. Journal of International Studies, 11(1): 140-151. doi:10.14254/2071-8330.2017/11-1/10

[03 12 2018]

Long, J. B., Plosser C. I. (1987) "Sectoral vs. Aggregate Shocks In The Business Cycle". American Economic Review, Papers and Proceedings, 77(2): 333-36.

Rose, A. K., Spiegel, M. (2009). Cross-country causes and consequences of the 2008 crisis: Early Warning. - http://www.frbsf.org/publications/economics/papers/2009/wp09-17bk.pdf [2012 01].

Schmukler, S. L., Zoido, P., Lalac, M. (2006). Financial Globalization, Crises, and Contagion.

http://siteresources.worldbank.org/DEC/Resources/32459_Schmukler,_Zoido,_and_Halac _(Oct2003).pdf [2012 01].

Shvedovsky, V., Standrik, A., Bilan, Y. (2016). Economic and Social Institutions: Modelling the Evolution Paths for the Archaic Society, Economics and Sociology, Vol. 9, No 2: 137-147. DOI: $10.14254 / 2071-789 X .2016 / 9-2$

Tase, Manjola (2016). "Sectoral Dynamics and Business Cycles, Finance and Economics Discussion Series 2016-066. Washington: Board of Governors of the Federal Reserve System, http://dx.doi.org/10.17016/FEDS.2016.066 [03 12 2018]

Zarnowitz V., Ozyildirim A. (2002). Time series decomposition and measurement of business cycles, trends and growth cycles // National Bureau of Economic Research, Working paper No. 6230. - January. 


\title{
ŽEMĖS ŪKIO SEKTORIAUS JAUTRUMAS CIKLINIAMS SVYRAVIMAMS: IRODYMAI IŠ EBPO NARIŲ IR POSOCIALISTINIŲ ŠALIŲ
}

\author{
Olena Tkachenko1, *Yuriy Bilan², Maryia Drobyazko ${ }^{3}$ \\ ${ }^{1,3}$ Kijevo nacionalinis ekonomikos universitetas, Ukraina \\ ${ }^{2}$ Alexander Bucek universitetas
}

Pateikta 201902 05; priimta 20190314

\begin{abstract}
Santrauka
Vykdant valstybės stabilizavimo politiką, svarbu atsižvelgti į įvairių ekonomikos sektorių jautrumą cikliniams svyravimams. To siekiant, kyla problema vertinant posocialistinių šalių agrarinio sektoriaus jautrumą ekonomikos cikliniams svyravimams. Šio straipsnio tikslas -dalies agrarinio sektoriaus jautrumo cikliniams svyravimams lyginamasis vertinimas išsivysčiusiose (poindustrinėse) ir posocialistinėse šalyse. Ciklinių svyravimų apibendrinamasis intensyvumo rodiklis panaudotas kaip aiškinamasis kintamasis, o kaip priklausomas kintamasis panaudota žemès ūkio sektoriaus dalies BVP kintamumo charakteristika (modifikuoto standartinio nuokrypio pagrindu). Gauti modelio parametru ìverčiai parodè, kad ilgalaikè agrarinio sektoriaus dalies mažèjimo tendencija nyksta. Nepaisant to, susilpnèjus grupès komponentų tendencijai, ciklinis komponentas lieka labai pastebimas, o žemès ūkio sektoriaus dalies santykiniai svyravimai (aplink labai žemą absoliutinę reikšmę) lieka dideli.

Raktiniai žodžiai: ekonominis ciklas, žemès ükis, ekonominio sektoriaus struktūra, cikliškumo intensyvumas, struktūriniai pokyčiai.

JEL kodai: E32, L16, O18.
\end{abstract}

* Autorius pasiteirauti 